\title{
PERSELINGKUHAN SUAMI TERHADAP ISTRI DAN UPAYA PENANGANANNYA
}

\author{
Kurnia Muhajarah \\ Universitas Islam Negeri (UIN) Walisongo Semarang \\ e-mail: kurniamuhajarah1@gmail.com
}

\begin{abstract}
Abstrak
Perselingkuhan pada umumnya banyak terjadi pada anggota keluarga yang kurang memiliki kualitas keagamaan yang mantap, lemahnya dasar cinta, komunikasi yang kurang lancar dan hamonis, sikap egois dari masing-masing, emosi yang kurang stabil, dan kurang mampu membuat penyesuaian diri. Metode penelitian ini adalah penelitian kualitatif. Hasil pembahasan menunjukkan bahwa problematika perselingkuhan suami terhadap istri adalah bahwa perselingkuhan dapat menjadi sumber stres yang luar biasa. Kegagalan pasangan untuk saling menyesuaikan diri dan memecahkan masalah-masalah secara efektif dapat memicu konflik yang berkepanjangan. Dari keselunuhan problematika perselingkuhan, problematika yang paling utama dari perselingkuhan adalah perceraian, karena perselingkuhan merupakan salah satu masalah putusnya perkawinan. Upaya penanganan perselingkuhan antara lain adalah mengawasi pergaulan suami atau istri, berupaya sekuat tenaga menciptakan suasana rumah tangga yang harmonis, berupaya memberi contoh yang baik, membangun lingkungan yang kondusif, meningkatkan kualitas nilai-nilai keagamaan, landasan cinta yang kokoh, mewujudkan komunikasi secara transparan dan harmonis, meningkatkan kekuatan dan ketahanan diri yang dilandasi dengan konsep diri dan rasa percaya diri secara mantap, mengembangkan kontak sosial secara baik dan sehat, bergaul dengan orang baik.
\end{abstract}

Kata Kunci: perselingkuhan; suami; penanganannya

\section{A. Pendahuluan}

Realita menunjukkan, janji kesetiaan yang diucapkan suami ketika akad nikah seringkali diabaikan, suami tergoda wanita lain sehingga terjadilah hubungan cinta dalam bentuk perselingkuhan. Hal ini tidak berarti perselingkuhan hanya terjadi pada pihak suami, istri juga banyak yang melakukan perselingkuhan, namun untuk mempersempit judul penelitian ini maka penelitian difokuskan pada perselingkuhan yang dilakukan seorang suami. 
Trend perselingkuhan banyak terjadi dalam kehidupan keluarga. Perselingkuhan merupakan salah satu aspek kehidupan keluarga dan sering menjadi sumber permasalahan. Perselingkuhan seorang suami merupakan bentuk penyimpangan tindakan anggota keluarga dilakukan tanpa sepengetahuan istrinya, demikian juga sebaliknya. Perselingkuhan dilakukan di berbagai aspek kehidupan keluarga, seperti keuangan, kebijakan keputusan, seksual, persahabatan, hubungan dengan orang tua, pekerjaan, dan sebagainya. Perselingkuhan biasanya ditandai dengan perubahan sikap. Perubahan sikap paling nyata dan sering terjadi dalam kasus perselingkuhan adalah kecenderungan untuk merahasiakan sesuatu, bertindak defensif (bersikap bertahan), dan berbohong. ${ }^{1}$

Perselingkuhan sebagai fokus pembahasan penelitian perlu dikaji dan diteliti karena relevan dengan maksud dan tujuan perkawinan yaitu membentuk keluarga sakinah, mawaddah dan rahmah. Perselingkuhan dapat mengurangi makna kebahagiaan perkawinan, namun masih saja terjadi sesuai dengan dinamika masyarakat dan perkembangan zaman. Interaksi yang tidak islami terutama di dunia kerja menjadi salah satu penyebab perselingkuhan selain faktor minimnya iman. ${ }^{2}$

Studi ini dimaksudkan untuk menjawab permasalahan bagaimana problematika perselingkuhan suami? Bagaimana upaya penanganan perselingkuhan? Permasalahan tersebut dibahas dengan data primer yaitu buku-buku atau kajian penelitian kepustakaan. Dalam pengumpulan data, peneliti menempuh langkah-langkah melalui riset kepustakaan (library research). Dalam menganalisis data, digunakan metode induktif dan metode komparatif.

\section{B. Perselingkungan}

Kamus Besar Bahasa Indonesia, selingkuh, secara etimologi diartikan sebagai perbuatan dan perilaku suka menyembunyikan sesuatu untuk kepentingan sendiri, tidak berterus terang, tidak jujur, dan curang. ${ }^{3}$ Menurut Blow dan Hartnett, perselingkuhan secara terminologi adalah kegiatan seksual atau emosional dilakukan oleh salah satu atau kedua individu terikat dalam hubungan berkomitmen dan dianggap melanggar kepercayaan atau

${ }^{1}$ Monty P. Satiadarma, Menyikapi Perselingkuhan, Jakarta: Pustaka Populer, 2010.

${ }^{2}$ Abu al-Gifari, Selingkuh Nikmat yang Terlaknat, (Bandung: Mujahid, 2012), h. 5.

${ }^{3}$ Depdiknas, Kamus Besar Bahasa Indonesia, (Jakarta: Balai Pustaka, 2002), h. 1021. 
norma-norma (terlihat maupun tidak terlihat) berhubungan dengan eksklusivitas emosional atau seksual. ${ }^{4}$

Pada prinsipnya, setiap orang menghendaki kehidupan normal dan dapat diterima dalam kehidupan sosial. Manusia secara kodrati mengikuti aturan-aturan kehidupan masyarakat, termasuk aturan dalam kehidupan berkeluarga, namun lingkungan pergaulan, jabatan, status sosial, dan pengalaman dapat mengubah seseorang. Demikian pula dalam kehidupan perkawinan, situasi semula demikian harmonis dapat berubah menjadi konflik dan pertengkaran ketika suami melakukan perbuatan perselingkuhan. Kenyataan ini terkadang sulit diatasi, bahkan tidak sedikit rumah tangga berakhir dengan perceraian. Perselingkuhan merupakan peristiwa menyakitkan bagi semua pihak, tidak hanya istri dan anak menjadi korban atau efek dari perselingkuhan, namun masyarakat pun mengecam perbuatan perselingkuhan.

Perilaku selingkuh dapat dikategorikan sebagai bentuk mekanisme pertahanan diri yaitu upaya mempertahankan keseimbangan diri dalam menghadapi tantangan kebutuhan diri. Kebutuhan-kebutuhan yang tidak tercapai dalam keluarga akan dicapai pemenuhannya secara semu dengan cara berselingkuh. Cara berselingkuh seolah-olah masalah yang dihadapi akan terselesaikan sehingga memberikan keseimbangan untuk sementara waktu, namun, karena cara itu merupakan cara yang semu dan tidak tepat, maka yang terjadi adalah timbulnya masalah baru yang menuntut untuk pemecahan lagi. ${ }^{5}$

\section{Data Perselingkuhan}

Data perselingkuhan menunjukkan bahwa terjadi kecenderungan meningkatnya jumlah kasus perselingkuhan. Harian Republika (12-8-2014) mensinyalir perselingkuhan sudah mengalami metamorphosis (perubahan bentuk) dari yang tidak lazim menjadi hal biasa, sehingga secara kualitatif dan kuantitatif eskalasinya (kenaikan) terus meningkat. Dalam penelitian yang respondennya adalah suami istri di Jakarta, Jawa Barat, Jawa Tengah, Jawa Timur, dan 10 Provinsi lainnya terungkap bahwa di antara suami istri yang pernah berselingkuh (di atas $40 \%$ istri, dan $75 \%$ suami).

\footnotetext{
${ }^{4}$ Anwar Bastian, "Perselingkuhan sebagai Kenikmatan Menyesatkan." Jurnal Psikologi Perkembangan, Volume 8, No. 2, Juni 2012.

${ }^{5}$ Mohammad Surya, Bina Keluarga, (Bandung: Graha Ilmu, 2009), h. 412.
} 
Tahun 2010, 60\% pria di Jakarta berselingkuh, 48\% dilakukan dengan PSK (pekerja Seks Komersial) dan 25,8\% melakukan hubungan seks extramarital dengan teman sekerja yang sudah menikah (Sarwono, 2013). Tahun 2011, persentase perselingkuhan meningkat $65 \%$ pria di Jakarta pernah berselingkuh, dan tahun 2012 perselingkuhan meningkat 70\%, tahun 2013 perselingkuhan meningkat 75\% (Sarwono, 2013). Perselingkuhan banyak dilakukan oleh semua lapisan masyarakat mulai rakyat biasa, kelas menengah, bahkan para eksekutif, lembaga legislatif, dan yudikatif. Kasus perselingkuhan di Jakarta disebabkan hasrat afeksi tertinggi yaitu akibat sering bertemu dengan rekan kerja perempuan. Pasangan selingkuh dengan rekan kerja menempati peringkat kedua (atau sekitar 23\%) setelah mantan pacar (atau sekitar 37\%). Berdasarkan data penelitian di atas menunjukkan bahwa perselingkuhan merupakan salah satu masalah putusnya ikatan perkawinan.

Menurut Hawari dalam Gifari mayoritas perselingkuhan dilakukan oleh kaum pria sementara wanita hanya 10\%. ${ }^{6}$ Perselingkuhan yang dilakukan oleh kaum pria didasari kepentingan mendapatkan kepuasan nafsu birahi. Masih ada anggapan bahwa selingkuh hanya boleh dilakukan oleh laki-laki. Selingkuh adalah salah satu bentuk perzinaan.7

Islam sebagai agama yang memiliki nilai dan aturan kehidupan telah menjelaskan bahwa perselingkuhan adalah kondisi yang tidak dibenarkan, dan merupakan perbuatan yang dilarang. Perselingkuhan merupakan perilaku dosa dan melanggar aturan agama. ${ }^{8}$ Sebagai firman Allah dalam surat al-Isra' ayat (32):

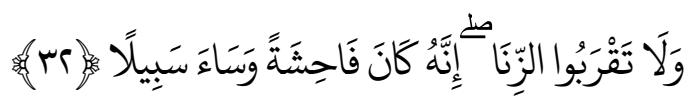

"Dan janganlah kamu mendekati zina; sesungguhnya zina itu adalah suatu perbuatan yang keji dan suatu jalan yang buruk."

Perselingkuhan merupakan perilaku zina karena mengakibatkan problematika kehidupan rumah tangga dan menjauhkan terwujudnya keluarga

${ }^{6} \mathrm{Abu}$ al-Gifari, Selingkuh Nikmat yang Terlaknat, h. 19.

${ }^{7}$ Ibid., h. 5.

${ }^{8}$ Monty P. Satiadarma, Menyikapi Perselingkuhan, h. 11.

${ }^{9}$ RHA. Soenarjo, dkk., al-Qur'an dan Terjemahnya, (Jakarta: Departemen Agama RI, 1998), h. 429. 
sakinah, mawaddah,warahmah. Allah berfirman dalam QS. al-Tahrim ayat 6 mengajarkan agar memelihara diri serta keluarga dari siksaan api neraka.

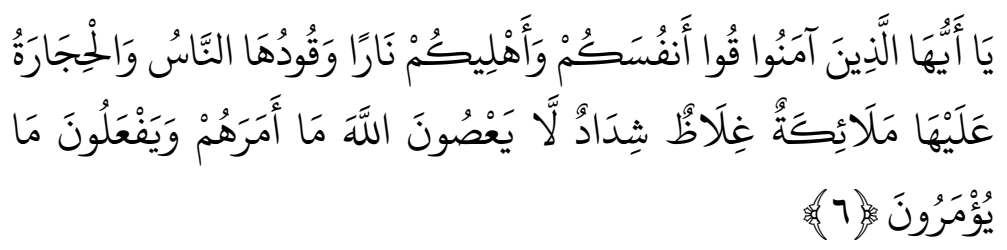

"Hai orang-orang yang beriman, peliharalah dirimu dan keluargamu dari api neraka yang bahan bakarnya adalah manusia dan batu; penjaganya malaikat-malaikat yang kasar, keras, dan tidak mendurhakai Allah terhadap apa yang diperintahkan-Nya kepada mereka dan selalu mengerjakan apa yang diperintahkan." 10

Berdasarkan ayat tersebut sebagai kepala keluarga harus menjaga dirinya sendiri serta keluarganya dari api neraka. Jika seseorang sudah masuk ke dalam neraka tidak ada yang dapat menolongnya, yang dapat menolong hanyalah sodaqoh jariyah, ilmu yang bermanfaat, dan anak shaleh.

Perselingkuhan terjadi di berbagai kalangan, seperti kasus yang terdapat pada Harian Suara Merdeka (2014) yaitu pelanggaran disiplin yang dilakukan Pegawai Negeri Sipil didominasi kasus perselingkuhan. Ada tiga kasus perselingkuhan yang melibatkan oknum guru serta PNS pada tahun itu. Perselingkuhan tersebut terjadi karena beberapa sebab, seperti pelarian emosional dari pasangannya, ingin merasakan seks dengan orang lain, marah atau benci dengan pasangan, variasi, menghindar dari masalah perkawinan atau pribadi, dan seterusnya. Suami atau istri pelaku tidak tahu perselingkuhan yang dilakukan pasangannya. Keterangan di atas menunjukkan, kemampuan untuk menyesuaikan diri dengan pasangan sangat dibutuhkan agar di antara pasangan tersebut dapat terjalin komunikasi yang baik sehingga perselingkuhan tidak terjadi.

\section{Faktor Penyebab Perselingkuhan}

Menurut Surya perselingkuhan pada umumnya banyak terjadi pada anggota keluarga yang kurang memiliki kualitas keagamaan yang mantap, lemahnya dasar cinta, komunikasi kurang lancar dan harmonis, sikap egois

\footnotetext{
${ }^{10}$ Ibid., h. 951.
} 
dari masing-masing, emosi kurang stabil, dan kurang mampu membuat penyesuaian diri. Di samping itu faktor lingkungan yang kurang kondusif dapat berpengaruh terhadap timbulnya perilaku selingkuh. Misalnya anak yang dibesarkan dalam situasi selingkuh cenderung akan menjadi pribadi kurang matang dan pada gilirannya cenderung akan menjadi manusia selingkuh. Dari sudut pendidikan anak, kondisi perselingkuhan merupakan lingkungan tidak menguntungkan bagi perkembangan anak. Dalam situasi demikian, sulit bagi anak untuk mendapatkan sumber-sumber keteladanan dan pegangan hidup. ${ }^{11}$

Menurut Gifari faktor-faktor terjadinya perselingkuhan antara lain:12 Pertama, ada peluang dan kesempatan. Bekerja di sebuah kantor ternama dengan posisi menjanjikan, ditemani sekretaris cantik dan seksi yang kesehariannya berpakaian mini dan ketat adalah peluang yang paling sering menjerumuskan seorang bos pada perselingkuhan. Pertemuan berlangsung terus menerus mengakibatkan hubungan pun begitu inten. Sekretaris umumnya mendampingi bos baik di kantor maupun di luar kantor, kadang terjebak pada rutinitas yang semakin membawanya pada rutinitas pelecehan seks dan berujung pada perselingkuhan.

Kedua, konflik dengan istri. Hubungan kurang harmonis dengan istri menjadi alasan paling sering diungkapkan pihak laki-laki untuk mencari kesenangan di luar. Apalagi jika konflik rumah tangga itu berakhir dengan pertengkaran hebat, akan sulit untuk mendamaikannya. Sementara kebutuhan seks datang tak terduga. Lambat-laun muncul hasrat untuk melampiaskannya di luar. Dalam masyarakat modern umumnya rumah tangga dibangun atas dasar gengsi baik karena alasan keluarga ningrat atau sebagai kaum the have. Mereka pandai menutup-nutupi borok yang terjadi di rumah tangganya, namun masing-masing pasangan mencari pelampiasan nafsunya di hotel-hotel atau berkumpul bersama teman selingkuhnya.

Ketiga, seks tidak terpuaskan. Para psikiater mengakui, banyak gangguan mental dan saraf bermula dari problema seksual. Gangguan-gangguan seksual juga bisa menimbulkan berbagai macam penyakit psikosomatik, berujung pada gangguan kesehatan fisik. Sehingga kesehatan emosional bergantung kepada suatu pengelolaan yang bijaksana dari aspek seksual.

${ }^{11}$ Mohammad Surya, Bina Keluarga, h. 412-413.

${ }^{12} \mathrm{Abu}$ al-Gifari, Selingkuh Nikmat yang Terlaknat, h. 24-31. 
Keempat, abnormalitas atau animalistis seks. Saat ini menjamur videovideo porno yang bisa didapatkan dengan harga relatif murah. Banyak suami sembunyi-sembunyi menonton tanpa sepengetahuan istri. Dia akhirnya mendapat informasi cara hubungan seks ala Barat serba vulgar dan cenderung tidak manusiawi (animalistis). Dia berharap dapat mengajak istri melakukannya seperti dilihatnya tadi, namun apa yang terjadi, banyak istri yang lugu kaget dengan keinginan suaminya itu. Tak sedikit yang berontak karena merasa tidak etis, suami sudah dirasuki seks ala binatang itu, akhirnya harus kecewa berat dan mencari pelampiasan di luar. Hal ini di antara salah satu abnormalitas seks berakibat ketidakcocokan di tempat tidur. Ada juga kasus, ketika sang suami merasa tidak puas berhubungan seks selang sehari. la memintanya hampir sehari tiga kali. Kasus ini juga mungkin disebabkan praktek-praktek seks yang sebelumnya dipanasi oleh tontonan kurang beradab itu. ${ }^{13}$

Kelima, iman yang hampa. Kosongnya iman adalah penyebab semua perilaku buruk. Begitu pula badai rumah tangga, merupakan bukti keroposnya bangunan iman. Iman akan menjamin seseorang tetap di jalur kebenaran karena orang beriman merasa segala tingkah lakunya diperhatikan Allah maka tidak mungkin seseorang beriman melakukan perselingkuhan (perzinaan) atau berbuat yang mendekatkan diri pada perzinaan..$^{14}$

Keenam, karena hilangnya rasa malu. Malu sebagian dari iman. Iman dan rasa malu seperti gula dengan manisnya atau garam dengan asinnya, yang keduanya tidak dapat dipisahkan. Sekalipun pembahasan iman di atas dinilai cukup, namun untuk lebih lengkap, rasa malu pun perlu dibahas lebih rinci. $^{15}$

\section{E. Karakteristik Perselingkuhan}

Perselingkuhan suami adalah suatu perbuatan suami yang tidak jujur atau bohong kepada diri sendiri dan atau pihak lain, dilakukan secara sembunyi-sembunyi melakukan hubungan dengan wanita lain sehingga kehidupannya berada dalam suasana yang tidak tenang. Karakteristik perselingkuhan adalah hubungan yang bersifat rahasia. Seseorang merasa rahasianya terancam maka cenderung bertindak untuk mempertahankan

\footnotetext{
${ }^{13} \mathrm{Abu}$ al-Gifari, Selingkuh Nikmat yang Terlaknat, h. 29.

${ }^{14}$ Ibid., h. 30.

${ }^{15}$ Ibid., h. 31.
} 
diri, misalnya mengatakan bahwa pertanyaan pasangannya bukan suatu bentuk pertanyaan tetapi bentuk interogasi. Pelaku selingkuh mengatakan bahwa pasangannya menyinggung perasaannya dengan pertanyaan tertentu, pasangannya kemudian mencoba tutup mulut. Pelaku perselingkuhan untuk sementara waktu berhasil menghindari ancaman pengungkapan. ${ }^{16}$

Pelaku selingkuh menjadi tambah waspada dengan ancaman yang mungkin timbul, pelaku kemudian menyusun sejumlah rencana baru untuk membohongi pasangannya. Pelaku selingkuh menyusun strategi ini bersama dengan pasangan perselingkuhannya, dan dilakukan secara rahasia pula. Kerahasiaan sebagai hal yang memperkuat perilaku perselingkuhan, dan sikap membangun kerahasiaan memperkuat sikap untuk melanjutkan perselingkuhan. ${ }^{17}$

\section{F. Perkawinan Pasca Perselingkuhan}

Menurut Hawari keberhasilan mempertahankan perkawinan pasca perselingkuhan bergantung pada beberapa faktor antara lain: ${ }^{18}$ pertama, Kesadaran dan pengakuan bahwa perselingkuhan itu adalah perbuatan yang melanggar norma-norma hukum perkawinan, moral etik agama. Atau dengan kata lain suami atau isteri yang berselingkuh itu menyadari dan mengakui kesalahannya. Kedua, Adanya penyesalan, rasa bersalah dan berdosa terhadap perselingkuhan yang telah dilakukannya dan berjanji tidak akan mengulanginya lagi. Ketiga, Adanya kesediaan dari suami atau isteri untuk melepaskan pasangan selingkuhnya. Keempat, Adanya motivasi dari pasangan suami isteri untuk berniat mempertahankan perkawinan. Motivasi ini harus datang dari kedua belah pihak. ${ }^{19}$

Sehubungan dengan hal tersebut di atas menurut Hawari terapis atau konselor hendaknya dapat menumbuhkan motivasi dan dalam proses psikoterapi keluarga itu dihindari agar pihak yang bersangkutan tidak merasa dipojokkan ataupun menjadi kehilangan muka. Konselor hendaknya dapat memulihkan kepercayaan pihak yang bersangkutan untuk berupaya meng-

\footnotetext{
${ }^{16}$ Monty P. Satiadarma, Menyikapi Perselingkuhan, h. 11.

${ }^{17}$ Anwar Bastian, “Perselingkuhan sebagai Kenikmatan Menyesatkan.” Jurnal Psikologi Perkembangan, Volume 8, No. 2, Juni 2012.

${ }^{18}$ Dadang Hawari, Marriage Counseling (Konsultasi Perkawinan), (Jakarta: Fakultas Kedokteran UI., 2006), h. 140.

${ }^{19} \mathrm{Ibid} ., \mathrm{h} .141$.
} 
ubah perilaku yang salah menuju perilaku benar dan dapat diterima oleh semua pihak, utamanya oleh keluarga, dalam hal anak istri. Konselor juga harus menumbuhkan semangat pada yang bersangkutan untuk terus berjuang membangun keluarga sakinah, mawaddah dan rahmah..$^{20}$

\section{G. Dampak Perselingkuhan bagi Anak}

Perselingkuhan memiliki dampak terhadap anak sebagai berikut:

1. Korban dari perselingkuhan orang tua, maka yang paling menderita adalah anak. Bila suami istri berselingkuh saat anak sudah dewasa, mungkin akibat perselingkuhan tidak akan terlalu berpengaruh pada si anak. Bila anak masih kecil, dampaknya tentu sangat terasa. Hal ini akan membuat si anak menjadi bingung dan merasa tidak nyaman karena keluarga sudah tidak bisa menjadi contoh yang baik. Anak bisa saja membenci orang tua yang selingkuh, dan hal itu tidak jarang terjadi pada keluarga yang berselingkuh.

2. Kebencian seorang anak terhadap orang tua bisa menimbulkan akibat lain, salah satunya adalah kelainan seksual. Misalnya, seorang anak perempuan membenci ayahnya yang telah menyakiti perasaan si ibu. Anak tersebut bisa saja membenci kaum pria dan kemudian beralih menyukai sesama jenis.

3. Orang tua adalah contoh bagi si anak. Bila orang tua berselingkuh, hal ini tentu bukan contoh yang baik. Namun, seorang anak bisa saja "mencontoh" hal ini ketika sudah berumah tangga. Bukan tidak mungkin si anak akan berpikir "orang tuaku saja pernah berselingkuh, berarti tidak apa-apa bila aku juga berselingkuh."

4. Akibat perselingkuhan yang lain adalah si anak bisa sangat tertekan, stres, atau depresi. Perasaan tertekan seperti ini bisa membuat si anak menjadi lebih pendiam, jarang bergaul, dan prestasi sekolahnya akan merosot.

5. Anak sebagai korban perselingkuhan orang tuanya tak selalu menjadi pendiam. Sebaliknya, seorang anak bisa menjadi pemberontak. Jiwa labil seorang anak yang sedang depresi bisa menggiringnya ke dalam pergaulan yang salah. Misalnya seks bebas, narkoba, atau bahkan kriminal.

${ }^{20}$ Ibid., h. 142. 
6. Trauma perselingkuhan tak hanya menghinggapi perasaan suami istri yang baru saja bertengkar, tapi juga berimbas pada si anak. Trauma yang terjadi pada anak bisa berupa timbulnya ketakutan untuk menikah.

\section{H. Upaya Menanggulangi Perselingkuhan}

Upaya menangani perselingkuhan harus melihat dari berbagai dimensi, idealnya harus menggunakan pendekatan multi disipliner atau interdisipliner, karena masalahnya mencakup berbagai aspek yang mempengaruhi.

Menurut Hamd guru besar Universitas al-Azhar Kairo, di antara halhal yang dapat membantu untuk mengobati gejala perselingkuhan ini seperti berikut: Pertama, bertakwa kepada Allah dan menumbuhkan sikap bahwa Allah selalu mengawasinya. Hal ini akan menenangkan jiwa untuk mendapatkan kepuasan, menjaga diri mengumbar pandangan. Sesungguhnya Allah Maha melihat sesuatu yang gaib bagi-Nya nyata, dan sesuatu yang rahasia jelas bagi-Nya. Kedua, merendahkan pandangan atau berpura pura tidak melihat. Orang yang merendahkan pandangannya, atau berpura-pura tidak melihat (wanita) berarti telah menaati Allah menenangkan hatinya, memelihara agamanya dan menyelamatkan gangguan yang menyeret pada terjerumusnya pandangan. Pepatah mengatakan: "menahan pandangan lebih mudah dari pada mendawamkan dukacita." Selain itu, merendahkan pandangan menumbuhkan kedekatan dengan Allah, keteguhan hati dan kegembiraan. Sebaliknya mengumbar pandangan, dapat melemahkan dan menyedihkan hati. Di samping itu, merendahkan pandangan, memupuk hati jadi kuat dan berani, mewariskan daya firasat yang benar dan membendung masuknya syetan ke dalam hati..$^{21}$ Ketiga, membiasakan merasa puas terhadap pemberian Allah. Jika seseorang membiasakan merasa puas, dia akan mendapat jalan menuju kepada kebahagiaan. Allah berfirman: "Dan janganlah kamu tujukan kedua matamu kepada apa yang telah Kami berikan kepada golongan-golongan dari mereka, sebagai bunga kehidupan dunia untuk Kami cobai mereka dengannya. Dan karunia Tuhan kamu adalah lebih baik dan lebih kekal.” (QS. Thaha: 131 ).

${ }^{21}$ Syekh Muhammad bin Ibrahim al-Hamd, Kesalahan-kesalahan Suami, (Surabaya: Pustaka Progressif, 2004), h. 139. 
Keempat, melihat orang yang lebih rendah dalam urusan materi (duniawi) dan melihat orang yang lebih tinggi dalam urusan agama dan segala kemuliaan. Inilah sebagai ukuran yang hakiki sebagai alat banding kemuliaan. Pandangan inilah yang membukakan mata manusia untuk mensyukuri nikmat Allah, sekaligus menghantarkannya untuk berterima kasih dan mengutamakan orang yang mendampingi dalam hidupnya. ${ }^{22}$ Kelima, memahami benar makna kecantikan dan ketampanan bukan satu-satunya faktor yang dapat merealisasikan kebahagiaan. Hamd menyuruh pembaca mencoba merenungkan kata-katanya: Anda misalnya menikah dengan ratu kecantikan sedunia, tetapi antara Anda dan isteri Anda (sebagai ratu kecantikan) itu sama sekali tidak ada kesepahaman, keserasian, cinta, kasih sayang, lalu apa yang Anda manfaatkan dari kecantikan isteri Anda itu?23

Menurut Syekh Muhammad Ibrahim, upaya menghindari perselingkuhan diantaranya: Pertama, menundukkan pandangan. Ibnul Jauzi berkata: "Orang yang secara tidak sengaja memandang sesuatu yang ia anggap baik, kemudian merasakan kenikmatan memandangnya, padahal perbuatan itu haram, maka wajib baginya untuk memalingkan pandangan. Ketika ia mengulangi pandangannya atau terus memandangnya, maka ia telah jatuh pada perbuatan tercela, baik menurut agama ataupun akal. ${ }^{24}$ Ketiga, merenung dan mengingat Allah. Orang yang sedang dimabuk asmara itu hendaklah berpikir terlebih dahulu sebelum melangkahkan kaki untuk menemui selingkuhannya. Sebab, selain ia menumpuk luka di atas luka, perbuatannya itu pun dicatat sebagai dosa di sisi Allah dan akan dimintai pertanggungjawabannya di akhirat kelak. ${ }^{25}$ Keempat, menjauh dari orang yang dicintai. Jauhnya jarak yang memisahkan tubuh seseorang dengan tubuh kekasihnya berdampak pada kerenggangan hati mereka. Oleh sebab itu, untuk pertama kalinya hendaklah ia bersabar, seperti kesabaran orang yang tertimpa musibah pada awal terjadinya. Lama-kelamaan, pasti perasaan tersebut akan hilang. ${ }^{26}$ Kelima, selalu mengikuti majelis dzikir. Hendaklah orang yang mabuk asmara selalu mengikuti majelis dzikir dan

22Ibid., h. 142.

${ }^{23}$ Ibid., h. 144.

${ }^{24}$ Syekh Muhammad Ibrahim, Taubat Surga Pertama Anda, (Jakarta: Pustaka Imam AsSyafi'i, 2009), h. 281.

${ }^{25} \mathrm{Ibid}$., h. 282.

${ }^{26}$ Ibid., h. 284. 
majelis para ahli zuhud serta sering mendengar berita tentang orang-orang shalih. Keenam, memutus keinginan dengan rasa putus asa dan berkemauan keras untuk menekan hawa nafsu. Sebab pertama munculnya rasa cinta adalah anggapan baik terhadap sesuatu, baik sesuatu itu muncul dari pendengaran ataupun penglihatan. Apabila pendengaran dan penglihatan tersebut tidak dibarengi dengan keinginan untuk memiliki orang yang dicintainya dan didukung dengan rasa putus asa, maka perasaan cinta itu tidak akan muncul. ${ }^{27}$

Selanjutnya menurut Surya, untuk menghindari perselingkuhan, Pertama, mewujudkan komunikasi secara transparan dan harmonis, atas dasar saling pengertian satu dengan lainnya. Kedua, meningkatkan kekuatan dan ketahanan diri, yang dilandasi dengan konsep diri dan rasa percaya diri secara mantap. Kondisi ini dapat membantu dalam kemampuan pengambilan keputusan secara tepat dan bertanggung jawab serta terhindarnya dari kemungkinan pengaruh-pengaruh negatif dari pihak lain. Ketiga, mengembangkan kontak sosial secara baik dan sehat, dalam pergaulan sosial melalui pola-pola hubungan antarpribadi baik di dalam maupun di luar keluarga. ${ }^{28}$

Salah satu upaya yang diduga dapat dilakukan untuk memberikan penanganan pada kasus perselingkuhan adalah dengan memberikan penanganan pada kasus perselingkuhan, dan dengan memberikan solusi menghindari terjadinya kasus perselingkuhan di dalam rumah tangga.

Berdasarkan uraian di atas, penulis setuju dengan upaya penanganan perselingkuhan dari berbagai ahli, namun penulis menambahkan bahwa selain upaya seperti yang dikemukakan di atas, maka upaya lain untuk penanganan perselingkuhan adalah:

\section{Niat dan Tekad}

Langkah paling mendasar untuk memulihkan perkawinan yang terkena goncangan akibat perselingkuhan adalah adanya niat dan tekad dari kedua belah pihak untuk memperbaiki hubungan perkawinan mereka. Niat adalah suatu keinginan, tetapi apabila tanpa dilandasi oleh tekad atau

${ }^{27}$ Ibid.

${ }^{28}$ Mohammad Surya, Bina Keluarga, h. 414. 
dorongan yang kuat agar terlaksana, maka segala upaya yang dilakukan akan pupus di tengah jalan. Niat sekadar mendorong seseorang merencanakan untuk melakukan langkah-langkah tertentu. Tekad memperkokoh niat tersebut untuk tetap dapat dilaksanakan sekalipun harus menghadapi berbagai tantangan yang besar. Dengan adanya tekad, seseorang akan lebih mampu bertahan menghadapi tantangan. Tanpa adanya tekad, niat mungkin hanya akan muncul pada awalnya kemudian pudar di tengah jalan.

Niat dan tekad tidak dapat dilakukan secara sepihak. Sebuah perkawinan merupakan hasil persekutuan dua entitas yang masing-masing memiliki kesediaan untuk menjadi bagian satu sama lain. Jadi, jika niat dan tekad hanya berlangsung pada satu individu saja sementara tidak pada individu lainnya, maka pelaksanaannya akan menjadi demikian sulit untuk diupayakan.

Dengan demikian hanya dengan tekad secara bersamalah pemulihan kelangsungan hidup perkawinan dapat diselenggarakan kembali. Di satu pihak pelaku perselingkuhan harus bertekad segera menghentikan kegiatan berselingkuhnya, di lain pihak pasangan lainnya harus bersedia menerima kembali pasangannya yang pernah berselingkuh. Akan tetapi justru hal inilah yang biasanya menjadi kendala besar dan perlu ditindaklanjuti dengan langkah-langkah nyata.

\section{Putus Selingkuh (Memutuskan Perselingkuhan)}

Istilah putus selingkuh ini digunakan karena masalah perselingkuhan ini ada banyak kemiripannya dengan ketergantungan obat. Langkah awal untuk memutuskan ketergantungan obat dikenal dengan istilah putus obat atau putus zat. Jadi, pengertian putus selingkuh ini sama kiranya dengan istilah putus dari ketergantungan pada obat.

Perselingkuhan memiliki banyak kesamaan pola perilaku dengan kecanduan; bahkan perselingkuhan merupakan bentuk candu asmara. Demikian kecanduannya seorang pelaku perselingkuhan sehingga sulit menjalani kehidupan sehari-harinya tanpa melakukan perselingkuhan. Ada individu yang melakukannya dengan pasangan selingkuh yang tetap, ada yang berganti-ganti pasangan, dan ada pula yang dikenal sebagai perselingkuhan semalam (one night stand). Perselingkuhan semalam biasanya dilakukan seseorang pada suatu peristiwa tertentu misalnya dalam suatu pesta. Mereka lalu berselingkuh pada malam tersebut dan tidak berencana 
untuk melanjutkan hubungan mereka. Pecandu perselingkuhan melakukan hal ini berulang-ulang jadi hampir di setiap pesta akan mencari seseorang pasangan untuk diajak berselingkuh.

Putus zat akibat ketergantungan menimbulkan perasaan tidak nyaman yang akan berlangsung selama jangka waktu tertentu. Penderita ketergantungan obat banyak yang mengalami berbagai gangguan halusinasi ketika konsumsi candu mereka dihentikan. Sebagai contoh, ada di antara mereka yang merasa gatal di sekujur tubuh, merasa diserang ribuan serangga, dan lain-lain. Ketika candu asmara dihentikan pelaku perselingkuhan pun akan merasakan ketidaknyamanan yang demikian besar. Mereka akan merasa kehilangan salah satu "aroma" kehidupan yang selama ini turut mewarnai hidup mereka. Hal yang paling sulit mereka atasi adalah secara sadar mereka harus memutuskan hubungan tersebut secara total.

Berbeda dengan rasa kehilangan akibat kematian seseorang. Rasa kehilangan ini hanya dapat diatasi dengan kesediaan menerima, karena yang sudah meninggal tidak akan kembali lagi. Akan tetapi dalam gejala putus zat atau putus selingkuh, baik zat maupun stimulus asmara masih tetap ada, dan kapan pun akan bisa diperoleh kembali. Pelaku harus memutuskannya dan mengalami rasa kehilangan tersebut. Artinya, untuk mengatasi masalah ini, pelaku harus secara sengaja bersedia memasuki situasi kehilangan (feeling of loss) yang memang tidak nyaman. Padahal selama ini justru mereka memperoleh ilusi rasa nyaman melalui perbuatannya tersebut.

Di dalam periode kehilangan akibat putus selingkuh, pelaku harus menghadapi beberapa hal, antara lain: harus bergumul dengan rasa gundah, sedih. Tak jarang menunjukkan bentuk-bentuk perilaku yang hampir sama dengan gejala depresi seperti kehilangan gairah kerja, kehilangan gairah makan, gairah bicara, dan sebagainya. Raut wajah mereka mungkin tidak terlalu menggembirakan. Pada saat bersamaan pula biasanya pasangan perkawinan menuntut mereka menampilkan perilaku yang menyenangkan.

\section{Kesediaan untuk Berubah}

Salah satu hal paling sulit dilakukan oleh seseorang adalah mengubah kebiasaan sekalipun kebiasaan tersebut membawa dampak buruk. Hal inilah yang merupakan penghambat terbesar untuk mengatasi masalah ketergantungan obat. Demikian pula dalam perselingkuhan. Individu yang 
terbiasa melakukan perselingkuhan akan sulit mengubah kebiasaannya untuk tidak lagi berselingkuh. Perasaan kehilangan seperti yang diutarakan di atas kerap mendorong individu untuk kembali mencari pasangan perselingkuhan. Perasaan yang dibutuhkan oleh pasangan perselingkuhan kerap mendorong individu untuk kembali berselingkuh. Individu yang bersangkutan harus memiliki kesediaan untuk berubah dalam pengertian mengubah gaya hidup serta kebiasaan-kebiasaannya, antara lain: a) Kebiasaan pulang kerja larut malam harus diubah menjadi pulang kerja pada saat yang wajar sesuai dengan jam kerja yang ditentukan, b) Kebiasaan mampir di bar seusai pulang kerja harus dihentikan.

\section{Menghindari Kelangsungan Hubungan}

Menghindari kelangsungan hubungan dengan pasangan perselingkuhan artinya tidak sama sekali kembali berhubungan. Hal ini banyak dianggap sebagai pendekatan yang radikal oleh sebagian orang. Ada sejumlah orang yang kemudian mengatakan ingin mempertahankan hubungan sebagai saudara, kakak, adik, atau partner usaha, dan sebagainya. Sungguh ideal memang jika seorang individu dapat mengubah perasaannya begitu saja dari asmara menjadi cinta antarsaudara. Hal ini bukan merupakan sesuatu yang tidak mungkin tetapi merupakan sesuatu yang memiliki risiko cukup tinggi, karena: a) asmara yang pernah tumbuh di suatu saat akan menjadi benih asmara untuk tumbuh lagi kelak bila peluang memungkinkan, b) Tidak terlalu mudah untuk memadamkan api asmara lalu mengubahnya menjadi cinta antarsaudara, apalagi sekadar membina hubungan selaku partner usaha, c) Ketika suatu saat perselisihan rumah tangga muncul, bukan tidak mungkin mantan pelaku perselingkuhan akan mengalihkan perhatiannya kembali ke individu lain, tempatnya menanam benih asmara.

\section{Menghindari Peluang Perselingkuhan}

Pendekatan ini pun oleh sebagian dianggap sebagai pendekatan radikal, karena upaya ini harus dilakukan bahkan mungkin individu yang bersangkutan harus pindah kerja, atau pindah tempat tinggal sekalipun.

\section{Berada Bersama Pasangan Perkawinan}

Keberadaan bersama pasangan perkawinan merupakan bukti paling nyata akan adanya niat dan tekad untuk mempertahankan keutuhan rumah tangga: a) Berada bersama secara fisik merupakan hal paling besar 
manfaatnya untuk menghindari peluang terjadinya perselingkuhan. Namun tentunya hal ini tidak selamanya bisa dilakukan, b) Sejumlah pakar konseling perkawinan bahkan mengajukan saran agar para pasangan rumah tangga dapat mengembangkan usaha bersama di dalam rumah mereka sehingga mereka tidak perlu lagi meninggalkan rumah untuk bekerja.

\section{Membina Komunikasi}

Komunikasi merupakan aspek sangat penting di dalam hubungan antarmanusia. Berada bersama tanpa komunikasi akan menghasilkan bentuk hubungan yang hambar.

\section{Kesimpulan}

Problematika perselingkuhan suami terhadap istri dapat menjadi sumber stres yang luar biasa. Kegagalan pasangan untuk saling menyesuaikan diri dan memecahkan masalah-masalah secara efektif dapat memicu konflik yang berkepanjangan. Dari keseluruhan problematika perselingkuhan, maka problematika yang paling utama dari perselingkuhan adalah perceraian, karena perselingkuhan merupakan salah satu masalah putusnya perkawinan. Perselingkuhan adalah penyebab utama perceraian.

Upaya penanganan perselingkuhan antara lain adalah mengawasi pergaulan suami, berupaya sekuat tenaga menciptakan suasana rumah tangga yang harmonis, berupaya memberi contoh yang baik, dan membangun lingkungan yang kondusif.[]

\section{Daftar Pustaka}

Akbar, Ali, Merawat Cinta Kasih. Jakarta: Pustaka Antara, 2011.

Amini, Ibrahim, Principles of Marriage Family Ethics, terj. Alwiyah Abdurrahman, Bimbingan Islam Untuk Kehidupan Suami Istri, Bandung: al-Bayan, 1999.

Ancok, Djamaludin, dan Fuad Nashori Suroso, Psikologi Islam: Solusi Islam atas Problem-problem Psikologi, Yogyakarta, Pustaka Pelajar, 1994.

Asriana, Widya, "Kecemburuan pada Laki-laki dan Perempuan dalam Menghadapi Perselingkuhan Pasangan Melalui Media Internet", Jumal Psikologi. Volume 1 Nomor 1. 
Bastian, Anwar, Perselingkuhan sebagai Kenikmatan Menyesatkan. Jurnal Psikologi Perkembangan, Volume 8, No. 2, Juni 2012.

Depdiknas, Kamus Besar Bahasa Indonesia, Jakarta: Balai Pustaka, 2002.

Freud, Sigmund, Three Contributions to the Theory of Sex, terj. Apri Dabnarto, Teori Seks, Yogyakarta: Jendela, 2003.

Gerungan, W.A., Psikologi Sosial. Bandung: Eresco, 1991.

Gunarsa, NY. Singgih D., dan Singgih D Gunarsa, Psikologi Keluarga, Jakarta: BPK Gunung Mulia, 1986.

al-Gifari, Abu, Selingkuh Nikmat yang Terlaknat. Bandung: Mujahid, 2012.

al-Hamd, Syekh Muhammad bin Ibrahim, Kesalahan-Kesalahan Suami, Surabaya: Pustaka Progressif, 2004.

Hamid, Zahry, Pokok-Pokok Hukum Perkawinan Islam dan Undang-Undang Perkawinan di Indonesia. Yogyakarta: Bina Cipta, 1978.

Handrianto, Budi dan Nana Mintarti, Seks dalam Islam. Jakarta: Puspa Swara, 1997.

Harahap, Syahrin, Islam Dinamis Menegakkan Nilai-nilai Ajaran al-Qur'an Dalam Kehidupan Modern di Indonesia. Yogyakarta: Tiara Wacana, 1997.

Hawari, Dadang, Marriage Counseling (Konsultasi Perkawinan). Jakarta: Fakultas Kedokteran UI, 2006. al-Qur'an, Ilmu Kedokteran Jiwa dan Kesehatan Jiwa. Yogyakarta: Dana Bhakti Primayasa, 1998.

Hedva, Widya. Dampak Perselingkuhan Bagi Pasangan Nikah dan Anak. Jumal Forum Psikologi. Volume 2 Nomor 3, 1992.

Ibrahim, Syekh Muhammad, Taubat Surga Pertama Anda, Jakarta: Pustaka Imam As-Syafi'i, 2009.

Jazairi, Abu Bakar Jabir, Minhâj al-Muslim, Kairo: Maktabah Dâr al-Turas, 2004.

Jaziri, Abdurrrahmân, Kitab al-Fiqh 'alâ al-Mazâhib al-Arba'ah. Beirut: Dâr al-Fikr, 1972.

Kasir, Ismâ'il ibn al-Qurasyî al-Dimasyqî,, Taffîr al-Qur'an al-Azîm., Beirut: Dâr alMa'rifah, 1978.

Latipun, Psikologi Konseling. Malang: UMM Press, 2005.

Lubis, Saiful Akhyar, Konseling Islami. Yogyakarta: eLSAQ Press, 2007. 
Mappiare, Andi, Pengantar Konseling dan Psikoterapi, Jakarta: Raja Grafindo Persada, 2002.

Moore, Julia Hartley, Selingkuh dan Fakta-fakta Tersembunyi di Baliknya. Jakarta: Gramedia Pustaka Utama, 2005.

Nisbet, Robert, Contemporary Social Problems, New York: Harcourt, Barce and World, 1961.

Pohan, M. Imran, Seks dan Kehidupan Anak. Jakarta: Asri Media Pustaka, 1990.

Qibtiyah, Alimatul, Paradigma Pendidikan Seksualitas Perspektif Islam: Teori dan Praktek. Yogyakarta: Kurnia Kalam Semesta, 2006.

Ramayulis, Pendidikan Islam dalam Rumah Tangga. Jakarta: Kalam Mulia, 1990.

Rusyd, Ibnu, Bidâyah al Mujtahid Wa Nihâyah al Muqtasid. Beirut: Dâr Al-Jiil, 1409 $\mathrm{H} / 1989$.

Sabiq, Sayyid, Fiqh al-Sunnah, Kairo: Maktabah Dâr al-Turas, 1970.

Sadarjoen, Sawitri Supardi, Bunga Rampai Kasus Gangguan Seksual. Bandung: Refika Aditama, 2005.

Sarwono, Sarlito Wirawan, Psikologi Remaja, Jakarta: Raja Grafindo Persada, 2013.

Satiadarma, Monty P., Menyikapi Perselingkuhan, Jakarta: Pustaka Populer, 2010.

Scult, Duane, Growth Psychology: Models of The Healty Personality. New York: Company International Officers, 1980.

Sudirman, Rahmat, Konstruksi Seksualitas Islam dalam Wacana Sosial, Yogyakarta: Media Presindo, 1999.

Suhendi, Hendi dan Ramdani Wahyu, Pengantar Studi Sosiologi Keluarga, Bandung: Pustaka Setia, 2001.

Sururin. Ilmu Jiwa Agama, Jakarta: Raja Grafindo Persada, 2004.

Surya, Mohammad, Bina Keluarga. Bandung: Graha Ilmu, 2009.

Utsman ath-Thawill, Ajaran Islam tentang Fenomena Seksual, Jakarta: Raja Grafindo Persada, 2000.

Vembriarto, Pathologi Sosial, Yogyakarta: Yayasan Pendidikan Paramita, 1984.

Wiramihardja, Sutardjo A., Pengantar Psikologi Abnormal. Bandung: Refika Aditama, 2005. 